\title{
The Role of Social Media in Promoting Ethics, Morals and Values
}

\author{
Muhammad Nazmul Huda*
}

\begin{abstract}
Over the last few years the nature of communication has undergone a substantial change and it is still changing. Especially the revolution in social networking systems has tremendously changed the way of social communication. Modern social media opens up the possibilities of learning, discovering and sharing ideas and interacting with one another. Ethics and values are the spiritual aspect of any religion and civilization. Islam is the comprehensive moral guide line for the whole mankind, which requires being spread out to them around the world. The Prophet (SAAS) also said, "Convey my teachings to the people even if it were a single sentence" (Bukhari, Hadith No. 667). So in the modern and cyber era, the practice of promoting moral values can be performed in many ways. Though there are no experimental studies regarding the use of social media in promoting ethics (dâ'wah), this study will shed light on the understanding of how social media should be utilized for this purpose. It recommends, therefore, that the social media should be used by religious callers to improve the scalability of their dā'wah towards contemporary societies.
\end{abstract}

Keywords: Social media, Network, Dā’wah, Morality and Sharing.

\section{Introduction}

Social Media has been changing the way of information and knowledge being shared in real-time. It is a popular platform for online sharing of knowledge and information among different groups of people. Social media have the possible fundamentality to change the nature of our social life, both on a personal and a communal level. The presence of the latest generation of Internet has created the possibility to make more interactive and real time communication. Social networks are increasingly being used by teachers, learners, businessmen and general people as an informal communication tool. Islam is a comprehensive way of life, and morality is one of the essential cornerstones of Islam. So, the researcher mentioned by ethics and values here to Islamic teaching and morality and he used an Arabic term 'dā'wah' to refer to promoting ethics, morals and values. In the Holy Qur'an this term has been used to indicate the process of calling or inviting mankind towards the truth or to the right

* Muhammad Nazmul Huda, Assistant Professor, Dept. of Sciences of Hadith \& Islamic Studies, International Islamic University Chittagong (IIUC). E-mail: nazmuliiucbd@gmail.com 
path prescribed for mankind by their Lord. The Qur'an say's: “Invite (mankind, O Muhammad) to the Way of your Lord (i.e. Islam) with wisdom (i.e. with the Divine Revelation and the Qur'an) and fair preaching, and argue with them in a way that is better (Quran, 16: 125)." A person who invites people to understand Islam through a dialogical process is called dā' $\overline{1}$ (caller). We know that the trend of social media adoption and its usage has been increased dramatically over past few years. Though social media is widely adopted and used at individual and group levels, the adoption and usage of social media for Islamic activities in particular for dā'wah are very limited. Most of the current adopters and users utilize the social media merely for entertaining and few of them are using it for dā'wah. But in the midst of the rapid development of information technology, the work of dā'wah should take advantage of the system and use it fully to disseminate the divine message. This study is a qualitative analysis of the importance of social media as a tool of effectual communication for the purpose of dā'wah. There are more than twenty social networking sites in the world. But this paper discusses only five selected social media which are popular in and are commonly used by Muslim societies. These five media, namely Facebook, YouTube, Twitter, Blog and Skype provide opportunities to be utilized for religious purposes. The researcher uses reliable online data to identify the current phenomenon of social media adoption and use among Muslim scholars and social workers.

\section{Definition of Social Media}

The term "Social Media" refers to the use of web-based technologies as well as mobile technologies to turn communication into an interactive conversation. Kaplan and Haenlein define social media as 'a group of Internet-based applications that build on the ideological and technological foundations of $5^{\text {th }}$ generation web technologies, which facilitates the creation and exchange of user-generated content. It consists of different Internet applications such as blogs, social networking sites, content communities, collaborative projects, virtual game worlds and social worlds'(Boyd, D. M., and N. B. Ellison, 2008: 211).

Social media differs from traditional or paper-based media in many ways, including reach, quality, frequency, immediacy and permanence. Social media operates in a dialogic communication system. This is in contrast to traditional media that operate under a monologic communication model. Social media can be classified into the following categories:

1. Social Networking Websites: A social networking site would permit a client to create profiles or personal homepages online and build up a communal network. 
The page can be modified as the user needs and it contains video clips, music files or photos. The most popular websites offering social networking presently are Facebook, MySpace, LinkedIn and Twitter.

2. Blogging: A blog is an online magazine where an individual, group, or company presents a documentation of activities, opinion, or beliefs. There are many websites that allow users to generate blogs without any cost like Blogspot.com, Wordpress.com, and blogger.com. Anyone can create a blog on these websites and these blogs can be accessed by anyone by typing the web address or URL. Another popular subcategory of blogs is micro blogging. Twitter.com is an example of micro blogging (Trisha Dowerah Baruah, 2012: 4).

3. Content Generating and Sharing Sites: Such kinds of websites serve as sources of information for various topics. Photo-sharing sites like Flicker.com, Video sharing sites like youtube.com, slide sharing sites like slideshare.com, document sharing sites like docstoc.com, etc. all fall under this category. These sites serve as free content for all users of the internet. Users can search for content, download and use the content offered on these sites without any cost (Trisha Dowerah Baruah, 2012: 4).

There are many classifications of social media from different perceptions. But this paper is not concerned to which group a social media should be categorized; instead, it concentrates on identifying the possibility of adoption of social media in promoting morality among the societies.

\section{Role of Social Media in Human Life}

The presence of social media has enabled a change of an individual role in a social network. Previously, a social network might be established around a close family or work friend ties in a limited geographic area. Meanwhile, a new social media technology has created the center of network on an individual rather than on a community group. Social media can be used to facilitate the social relationship, increase self-esteem, and life satisfaction. Social media also has the ability to exchange questions and answers in a short time among involved people and can also be used for marketing and promotion tools.

The use of the internet, as well as social media is increasing day by day. Global active internet users are now 3.175 Billion in total, which is nearly half of the world's population (7.357 Billion). As for Social Media, there are over 2.206 Billion active users, a worldwide penetration of 30\%. 1.925 Billion of users utilize their mobiles for Social Media platforms. Facebook adds half million new users every day; 6 new profiles every second. Mobile users constitute half of the world's population and 2 
million smart phones are being sold worldwide every single day (Social Media Today, 2015).

World Facebook users by the end 2011 were 799 million in number, then increased to about 835 million by March 2012 and as of the fourth quarter of 2016, Facebook had 1.86 billion monthly active users (Statista, 2017). Meanwhile, Facebook users in Bangladesh have also sharply increased in last few years. Other social networks are also increasing continuously.

According to the study from the University of Maryland, now people spend 22\% of their online time on social networking such as Facebook, Twitter, YouTube, and Weblog. If Facebook is a country, then it will become the third largest country in the world that carried more than 1.65 billion monthly active users as of March 2016 (Facebook Reports First Quarter, 2016). If we put together the world's largest countries with the Networked Society, we find that the world's populations are now seen in a different way, as you see (Poyan Sandnell, 2014):

1. China, 2. India, 3. Facebook, 4. Whats App, 5. United States, 6. Google+, 7. Indonesia, 9. Linkedin, 10. Twitter

The concept of social media is at the top of the agenda for many social and business executives today. Stakeholders, as well as consultants are trying to recognize ways in which firms can make profitable use of social media applications.

With the birth and rise of social media, internet users in the Arab world were quick to embrace the new technology to connect, communicate and share information with others. The popularity of social media platforms in the Arab World has led some scholars to expect its impact on religious life to rise. The common argument is that social media has the potential to change people's religiosity and practices of piety. The scenario and statistics are almost same in the remaining Muslim world. The use of social media is not limited to religious leaders. Regular Muslims also tweet and post Qur'anic verses and hadith (prophetic sayings). The dissemination of religious content regularly reaches its peak during the 'Ramadan Aperture', when Muslims are internally and externally motivated to receive and process religious content in form of tweets. This new phenomenon changes the way the Islamic faith is promoted among believers and non-believers alike. So, based on the statistical review it argued that dā'wah is also an aspect that potentially adopts and utilizes social media to effectively deliver Islamic teachings by Muslims in general, and Muslim scholars in particular.

\section{Some Popular Social Media Tools and Scope of Moral Activities}

The following sub-sections will present some popular social media tools and strategy of use in promoting morality, ethics and values (dā'wah). 


\section{Facebook}

Facebook is the largest social network in the world. It has more than 1.86 billion monthly active users as of March 2017. Users create a personal profile, add other users as friends, and exchange messages, including status. Brands create pages and Facebook users can "like" brands' pages. According to Arab Social Media Report, 2014 in the Arab World, Facebook was still the leading social networking website with 81,302,064 users (Arab Social Media Report, 2014). Youth represents the majority of social media users in the Arab world; as of June 2013, the percentage of total users between 16 and 34 years was 77\%. Also, in May 2014 the percentage of total Facebook users between 15 and 29 years old reached to $67 \%$.

This scenario and statistics tell that, Facebook can be a strong platform for dā'wah activities.

Some Islamic scholars already have taken it as tools of their dā'wah. For example, we can remember Mohamad bin Abdel Rahman al-Arefe who is an Islamic theologian from Saudi Arabia. He is a professor at King Saud University. $\mathrm{He}$ is very popular in social media; as of December 9, 2015, Al-Arefe had over 16 million likes on Facebook and 13.4 million followers on Twitter, which places his account in the top 100 worldwide, and first in the Middle East (Wikipedia, 2016). Thus a number of Muslim scholars have established some Facebook groups to allow discussion and sharing information among them and Muslim communities.

\section{YouTube}

YouTube is a global video sharing website. It was firstly launched in May 2005. Communities can utilize the YouTube by uploading and downloading videos for their purposes. The presence of YouTube has enabled Muslim communities to share videos among them. Muslims are able to download or upload videos related to dā'wah to be viewed across the globe. A lot of dā'wah related videos can be found on YouTube. Even, when searching the term "Islam" on the YouTube, we find thousands of videos related to Islam in just less than one second. According to daily YouTube views, the Arab region is just second to the USA. With 90 Million video views per day, Saudi Arabia has the world highest number of YouTube views per Internet user (Arab News, 2014). This shows that YouTube has become an interesting alternative instrument to deliver dā' wah because the dā' wah can be delivered in an audio visual format. The presence of YouTube has also rocketed a number of da'i popularity in just a few weeks. For example, Nouman Ali Khan from America has become very popular when his religious speech was posted on the YouTube. It can be acknowledged that he is a very talented da'i, but his talent would not have put him at the top of popularity without YouTube. In addition, his dā'wah messages and style 
could not be enjoyed by millions of Muslims across the world. He has many video lectures on the YouTube. One of his YouTube posts was viewed by 1,18,420, persons (Nouman Ali Khan, Youtube).

The ability of YouTube to present audio visual mode of dā'wah has increased the number and scalability of dā'wah penetration within Muslim communities compared to a conventional method. Muslims are able to do dā'wah activities round the clock. A number of dâ'wah videos uploaded to YouTube show the average number of visitors are more than 10 thousand, some of them having more than 50 thousand visitors (Nurdin-Rusli, 2013:16). This phenomenon implies that YouTube is able to make massive dā' wah penetration into various communities without being impeded by time and space. A da'i can upload their videos on YouTube free of charge and people can view it anytime they want to watch. Realizing these impacts, it is time for a da'i to adopt and utilize YouTube for dā'wah purposes.

\section{Twitter}

Twitter a social networking and micro-blogging platform that allows groups and individuals to stay connected through the exchange of short status messages (140 character limit). As of May 2015, Twitter has more than 500 million users, out of which more than 302 million are active users. Almost 2 out of 5 users in the Arab World (39\%) consider Twitter their most favorite social media channel. Preference for Twitter was highest in Jordan and Libya (63\% and 50\%, respectively), while the users in Lebanon and KSA (24\% each) were the least, compared to other countries (Arab Social Media Report, 2015: 36). Twitter is also commonly popular amongst Islamic preachers.

\section{Blog}

The blog is a platform for informal dialogue and discussions on a specific topic. Blog has become very popular among individuals and groups. A number of public figures, such as celebrities and professionals, have established personal Blogs. Very few da'i's have Blog. Through blogs a da'i can deliver dā'wah more effectively to their communities. Even after he passes away, his dā'wah can still be delivered because his thoughts remain available on Internet and Muslim communities can access it at any time and from anywhere. Muslim communities can post their comments or ask questions to the blog owner. These interactive facilities enable Muslims to exchange their ideas and knowledge anytime effectively. The Blog also promotes new Islamic books which can be purchased online by visitors (Nurdin-Rusl, 2013: 1). Blogs appear to act as publishers of immediate information, easily accessible and answering medium for all religious issues. 
Skype

Skype is an application that specializes in providing video chat and voice calls. Users can also exchange text and video messages, files and images, as well as create conference calls. Skype is available on Microsoft Windows, Mac, or Linux, as well as Android, Blackberry, IOS and Windows Phones, Smart phones and tablets. Much of the service is free, but users require Skype Credit or a subscription to call landline or mobile numbers. As of February 2012, there were 34 million concurrently online on Skype. At the end of 2010, there were over 660 million worldwide users, with over 300 million estimated active each month as of August 2015 (Wikipedia, 2015). This tool can be used for various dā' wah activities like video conference, discussion, sending files, dā'wah related soft books, etc.

Other social media apps like Ummaland, Flickr, Instagram, LinkedIn Group, Whatsapp, Google Plus, Instagram, are also useful for dā'wah. Media and communication are considered as important means of dā'wah. The communication system differs from one place to another based on the level of people's civilization. In the days of Prophet Muhammad (SAAS), for instance, the work of dā'wah was carried out through all possible communication system. The Prophet (SAAS) used every contemporary social media to spread his divine message, for example: using poetry against enemy, dā'wah at fairs and markets, dā'wah through letters, dā'wah from the mountain top, dā'wah among pilgrims, etc. (Puthige, 1997).

\section{Conclusion}

According to the study, we find that: (1). the role of web-based social media is immense in social system. For instance, Facebook is the largest public platform in the globe and it is being increased day-by-day, (2). Prophet Muhammad (SAAS) also used all possible social communication systems for preaching Islamic teachings, and (3). few religious scholars already proved efficiency of social communication system through their moral activities across the globe using social media. So based on these observations, this study recommends that the social media should be used extensively to improve the scalability of dā'wah activities towards modern society. Moreover, dā'wah strategies need also to be redesigned in response to the new advancement in social communication technology. Adoption and use of modern social media for dā'wah not only would increase Muslim audience, but also could potentially attract other non-Muslim communities to understand Islam properly. 


\section{References}

Al Qur'an

Ali, A. (1981). Kanjul Ummal, Hadith No. 7995, Institute of Risalah, Beirut, Vol. 3, p. 580.

Arab News. (March 7, 2014). Available at http://www.arabnews.com/news/536196) [Retrieved on April 12, 2016].

Arab Social Media Report. (2014). Arab Social Media Influencers Summit, p.15, 37.

Baruah, T. D. (2012). Effectiveness of Social Media Tools, International Journal of Scientific and Research Publications, 2(5): 4.

Boyd, D. M., and Ellison, N. B. (2008). Social Network Sites: Definition, History, and Scholarship, Journal of Computer-Mediated Communication, 13(1): 211.

Bukhari, As-sahih, Vol. 4, Book- 56, Hadith No. 667.

Facebook Reports First Quarter. (2016). Available at http://www.prnewswire.com/newsreleases/facebook-reports-first-quarter-2016-results-and-announces-proposal-for-newclass-of-stock-300258749.html [Retrieved on February 12, 2017].

Khan, N. A. (2017). Available at https://www.youtube.com/watch?v=KqNfitp14vc [Retrieved on January 12, 2017]

Puthige, A. S. (1997). Towards Performing Dā’wah, United Kingdom: ICH, p. 109.

Rusli, N. (2013). Spiritualizing New Media, Jurnal Komunikasi Islam, 3(1): 13-16, Available at https://www.ericsson.com/thinkingahead/the-networked-societyblog/2014/07/14/know-facebook-third-largest-country-world/ [Retrieved on April 12, 2017]

Social Media Today, Available at http://www.socialmediatoday.com/ [Retrieved on April 12, 2017]

Social Media Usage in Middle East, Available at http://www.go-gulf.ae/blog/social-mediamiddle-east/ [Retrieved on April 12, 2016]

Statista, The Portal for Statistics, Available at https://www.statista.com/statistics/264810/number-of- monthly-active-facebookusers-worldwide/ [Retrieved on April 10, 2017]

Wikipedia, Available at https://en.wikipedia.org/wiki/Mohamad_al-Arefe\#cite_note-2 [Retrieved on May 12, 2016]

Wikipedia, Available at https://en.wikipedia.org/wiki/Skype [Retrieved on April 12, 2016] 